Огляди літератури, оригінальні дослідження, погляд на проблему, ювілеї УДК 616.379-008.64-06:616.71-007.234]-085.214.24.065

DOI 10.11603/1811-2471.2018.v0.i3.9281

\title{
СТАН ОКСИДАТИВНОГО СТРЕСУ У ХВОРИХ З ПОЄДНАНИМ ПЕРЕБІГОМ ЦУКРОВОГО ДІАБЕТУ 2 ТИПУ ТА ОСТЕОПОРОЗУ
}

\section{ФВ. І. Кривенко, О. І. Бородавко}

Запорізький державний медичний університет

РЕЗЮМЕ. Одним із факторів, який може впливати на розвиток та прогресування як цукрового діабету 2 типу (ЦД), так і остеопорозу (ОП), є оксидативний стрес (ОС). Однак, у літературі ми не знайшли повідомлень про виразність ОС у хворих з поєднаним перебігом ЦД та ОП.

Мета роботи - оцінити стан оксидативного стресу у хворих з поєднаним перебігом цукрового діабету 2 типу та остеопорозу.

Матеріал і методи. У дослідження включено 94 особи (від 50 до 70 років). До 1 групи увійшли 22 хворих на ОП, до 2 - 22 пацієнти з ЦД, до 3 - 50 хворих з поєднаним перебігом ЦД та ОП. Усім пацієнтам проводили ультразвукову денситометрію на ультразвуковому денситометрі Omnisense 7000 (BeamMedLtd, Iзраїль). Oцінку стану кісткової тканини проводили за критеріями ВООЗ. Інтенсивність ОС оцінювали за рівнем нітротирозину у сироватці крові. Пацієнтам з ЦД проводили дослідження глюкози натще, HbA1c, інсуліну та розрахунок індексу HOMA.

Результати. У хворих з поєднаним перебігом ЦД та ОП має місце збільшення виразності ОС, що підтверджено достовірним зростанням рівня нітротирозину у 2,8 раза, порівняно з хворими з ізольованим перебігом ОП, та у 2,1 раза - з ЦД ( $p<0,05)$. Рівень нітротирозину має вірогідний позитивний взаємозв'язок з НbA1c $(r=+0,29, p<0,05)$. Тривалість ЦД понад 10 років супроводжується підвищенням рівня нітротирозину у 2,3 раза, порівняно з пацієнтами, які хворіють на ЦД до 5 років $(p<0,05)$. Рівень нітротирозину асоціювався з параметрами ультразвукової денситометрії, що підтверджено зворотним взаємозв'язком нітротирозину та Т-індексом променевої кістки ( $r=-0,29, p<0,05)$, Т-індексом фаланги $(r=-0,25, p<0,05)$.

Висновки. У пацієнтів з поєднаним перебігом ЦД та ОП відбувається інтенсифікація оксидативного стресу, яка може бути проявом синдрому «взаємного обтяження». Логічно припустити, що поряд із стандартною терапією, ці хворі повинні отримувати і препарати з антиоксидантними властивостями.

КЛЮчОВІ СЛОВА: оксидативний стрес, цукровий діабет 2 типу, остеопороз.

Вступ. Проблема поєднаного перебігу цукрового діабету 2 типу (ЦД) та остеопорозу (ОП) полягає не тільки в значній поширеності цих патологічних станів у клінічній практиці терапевтів, сімейних лікарів, а й у відсутності єдиних поглядів на патогенез їх коморбідності [1].

Одним із факторів, який може впливати на розвиток та прогресування як ЦД, так і ОП $є$ оксидативний стрес (OC) - пошкодження тканин у результаті збільшення кількості активних форм кисню та недостатності антиоксидантного захисту [2]. Одним із найсильніших окисників $є$ пероксинітрит, який викликає нітротрозування білків, розриви ДНК, мітохондріальну дисфункцію та апоптоз [3]. Проте пероксинітрит $\epsilon$ нестабільною сполукою і оцінити його концентрацію у сироватці крові практично неможливо. Тому у клінічній практиці для визначення патологічної активності пероксинітриту використовують нітротирозин, який утворюється при взаємодії тирозину з пероксинітритом. Дослідження рівня нітротирозину - специфічного маркера окисного ушкодження білків, проаналізовано науковцями при різних патологічних станах [4]. Однак у літературі ми не знайшли повідомлень про виразність ОС у хворих з поєднаним перебігом ЦД та ОП.
Мета дослідження: оцінити стан оксидативного стресу у хворих з поєднаним перебігом цукрового діабету 2 типу та остеопорозу.

Матеріал і методи дослідження. У дослідження включено 94 особи (від 50 до 70 років), які постійно проживали у м. Запоріжжі та проходили амбулаторне та стаціонарне лікування на базі навчально-наукового медичного центру «Університетська клініка» Запорізького державного медичного університету. До 1 групи увійшли 22 хворих на ОП, до 2 - 22 пацієнти з ЦД, до 3 - 50 хворих з поєднаним перебігом ЦД та ОП. Виділені групи статистично не різнилися за статтю та віком. Пацієнти 2 та 3 груп мали середню важкість перебігу захворювання та достовірно не відрізнялися за тривалістю анамнезу ЦД. Проте у хворих 2 та 3 груп зареєстровано істотні відмінності рівнів глікозильованого гемоглобіну, відповідно $7,8 \%(6,4 ; 9,0)$ та $8,7 \%(7,9 ; 10,6)$, та індексу HOMA, відповідно 12,5 ум. од. $(9,4 ; 13,9)$ та 13,4 ум. од. $(12,0 ; 16,5),(p<0,05)$.

Критерії включення у дослідження: підписана інформована згода пацієнта на участь у дослідженні, верифікований діагноз цукрового діабету, вік від 50 до 70 років. Критерії виключення: цукровий діабет 1 типу, вторинно інсулінозалеж- 
Огляди літератури, оригінальні дослідження, погляд на проблему, ювілеї

ний ЦД, прийом глюкокортикостероїдів понад 3 місяці, порушення функції щитоподібної залози, хронічна серцева недостатність, хронічна хвороба нирок, системні захворювання сполучної тканини, наявність передчасної (до 45 років) або штучної менопаузи у жінок.

Усім пацієнтам проводили ультразвукову денситометрію на ультразвуковому денситометрі Omnisense 7000 (BeamMedLtd, Ізраїль) по трьох кістках: проксимальна фаланга III пальця кисті, дистальний відділ 1/3 променевої кістки, середина великогомілкової кістки. Оцінку стану кісткової тканини проводили за критеріями ВОО3: нормальний стан - Т-критерій > -1,0 SD, остеопенія Т-критерій - від -1,0 до -2,5 SD, остеопороз Т-критерій <-2,5 SD [5].

Інтенсивність оксидативного стресу оцінювали за рівнем нітротирозину (набір реактивів фірми Hycult Biotech, Нідерланди) у сироватці крові, який досліджували імуноферментним методом на мікропланшетному фотометрі Immunochem-2100 (High Technology, США). Глюкозу натще та глікозильований гемоглобін (НbA1c) досліджували у сироватці крові на біохімічному аналізаторі Prestige 24і (Tokyo Boeki, Японія). Пацієнтам з ЦД 2 типу визначали рівень інсуліну (набір реактивів фірми Monobind Inc., США) за допомогою імуноферментного методу на мікропланшетному фотометрі Immunochem-2100 (High Technology, США) з подальшим розрахунком індексу НОМА за стандартною методикою [6].

У роботі дотримано принципів біоетики: основних положень Конвенції Ради Європи про права людини та біомедицину (від 04.04.1997р.), GСР (1996 р.), Гельсінкської декларації Всесвітньої медичної асоціації про етичні принципи проведення наукових медичних досліджень за участю людини (1964-2000 рр.) і наказу МОЗ України № 281 від 01.11.2000.

Статистичну обробку проводили за допомогою комп'ютерної програми «Statistica 13.0» for Windows(StatSoft Inc., № JPZ8041382130ARCN10-J). Аналіз показників на нормальність розподілу проводили методом Шапіро-Уілка. Дані описової статистики представлені у вигляді середнього арифметичного та стандартного відхилення при нормальному розподілі ознак, а при розподілі, що відрізняється від нормального, -у вигляді медіани та міжквартильного розмаху. Порівняння параметрів у досліджуваних групах проводили за допомогою залежно від розподілу ознаки. Для визначення характеру та сили зв'язку між досліджуваними показниками використовували коефіцієнт кореляції Пірсона або Спірмана, залежно від характеру розподілу даних. Статистично значущими вважали відмінності при $\mathrm{p}<0,05$.

Результати й обговорення. Як показали результати дослідження, у хворих з поєднаним перебігом ЦД та ОП зареєстровано достовірне підвищення рівня нітротирозину - у 2,8 раза $(p<0,05)$, порівняно з першою, та у 2,1 раза - з другою групами $(p<0,01)$ (табл. 1). Отримані дані вказують на високу окиснювальну деструкцію оксиду азоту у обстежених нами пацієнтів і свідчать про істотну інтенсифікацію хронічного оксидативного стресу.

Таблиця 1. Рівень нітротирозину у хворих на цукровий діабет 2 типу, остеопороз, та при поєднаному їх перебігу

\begin{tabular}{|c|c|c|c|}
\hline Показник & $\begin{array}{c}\text { Хворі на ОП } \\
(1 \text { група) } \\
\mathrm{N}=22\end{array}$ & $\begin{array}{c}\text { Хворі на ЦД } \\
(2 \text { група) } \\
\mathrm{N}=22\end{array}$ & $\begin{array}{c}\text { Хворі на ЦД та ОП } \\
\text { (3 група) } \\
\mathrm{N}=50\end{array}$ \\
\hline Нітротирозин, нмоль/мл & $18,9(12,1-31,3)$ & $14,4(12-18,1)$ & $41,4(11,7-56,5)$ *\# \\
\hline
\end{tabular}

Примітка. * - p<0,05 у порівнянні з пацієнтами 1 групи; \# - p<0,01 у порівнянні з пацієнтами 2 групи.

3 літератури відомо, що ОС впливає як на розвиток ЦД, так і на порушення кісткового метаболізму. Так, на тлі ЦД на 45,7 \% знижується рівень супероксидисмутази [7], реєструється підвищення нітротирозину, малонового альдегіду, оксиду азоту, тіолового статусу [8]. Логічно припустити, що стан ОС може залежати від тривалості перебігу ЦД, рівнів глікемії та глікозильованого гемоглобіну. Тому ми проаналізували рівень нітротирозину в залежності від показників вуглеводного обміну.

Для рішення поставленої задачі пацієнтів 3 ЦД було поділено, залежно від рівня HbA1c, на дві групи: до групи 1.1 включені пацієнти, які мали концентрацію НbA1c $\leq 7,5 \%$, до групи 1.2 - хворі 3 HbA1c > 7,5 \% [9]. Як випливає з даних таблиці 2,

Таблиця 2. Рівень нітротирозину у хворих на цукровий діабет 2 типу залежно від перебігу захворювання

\begin{tabular}{|c|c|c|}
\hline Показник & Група 1.1 (HbA1c $\leq 7,5 \%)$ \\
$\mathrm{N}=31$ & $\begin{array}{c}\text { Група 1.2 } \\
\text { (HbA1C }>7,5 \%) \\
\mathrm{N}=41\end{array}$ \\
\hline Нітротирозин, нмоль/мл & $15(10-44)$ & $40,9(12-60)^{*}$ \\
\hline
\end{tabular}

Примітка: * $-p<0,01$ 
Огляди літератури, оригінальні дослідження, погляд на проблему, ювілеї

недостатній вуглеводний контроль (НbA1C>7,5\%) у пацієнтів з ЦД асоціювався із підвищенням рівня нітротирозину у 2,7 раза, порівняно з хворими, які мали $\mathrm{HbA} 1 \mathrm{C} \leq 7,5 \%$ ( $<<0,01)$. У дослідженні Азізової Г. І. (2014) декомпенсація ЦД також супроводжувалась підвищенням маркерів ОС та зниженням показників антиоксидантного захисту [8].

За даними дослідників, процеси вільнорадикального окислення у хворих на ЦД можуть невпинно прогресувати [10]. Для розгляду цієї гіпоте- зи обстежених пацієнтів з ЦД було поділено на 3 групи (табл. 3). Визначено, що у хворих з тривалістю ЦД понад 10 років, рівень нітротирозину у 2,3 рази був вищим, ніж у пацієнтів з анамнезом ЦД до 5 років $(p<0,05)$. За даними науковців, у хворих на ЦД підвищення рівня нітротирозину асоціювалось зі зниженням показників антиоксидантного захисту [11]. Можемо припустити, що, очевидно, цій категорії пацієнтів потрібне призначення препаратів із антиоксидантими властивостями.

Таблиця 3. Рівень нітротирозину у пацієнтів з цукровим діабетом 2 типу залежно від тривалості захворювання

\begin{tabular}{|c|c|c|c|}
\hline Показник & $\begin{array}{c}\text { Тривалість ЦД } \\
\leq 5 \text { років }\end{array}$ & $\begin{array}{c}\text { Тривалість ЦД } \\
\text { Від 5-10 років } \\
\mathrm{N}=31\end{array}$ & $\begin{array}{c}\text { Тривалість ЦД } \\
\geq 10 \text { років } \\
\mathrm{N}=14\end{array}$ \\
\hline Нітротирозин, моль/мл & $14,5(10-42)$ & $19,1(12-59)$ & $34,1(16-62) *$ \\
\hline
\end{tabular}

Примітка. * - p<0,05 у порівнянні з пацієнтами з тривалістю цД до 5 років.

Для оцінки рівня нітротирозину та ступеня ураження кісткової тканини, за даними ультразвукової денситометрії всі пацієнти були поділені на групи залежно від кількості кісток з Т індексом $\leq-1,0$ SD (остеопенія та ОП). Як випливає з таблиці 4, найбільше підвищення рівня нітротирозину, діагностоване у групі пацієнтів із зниженням Т-індексу (остеопенія, ОП) за 3-ма кістками (фаланга, променева та великогомілкова кістки) у 3,8 раза, порівняно з групою з нормальною мінеральною щільністю кісткової тканини (МЩКТ) $(p<0,05)$.

Таблиця 4. Рівень нітротирозину залежно від ступеня виразності зниження мінеральної щільності кісткової тканини

\begin{tabular}{|c|c|c|c|c|}
\hline Показник & $\begin{array}{c}\text { T-індекс } \\
>-1.0 \mathrm{SD} \\
\text { МЩКТ у нормі } \\
\mathrm{N}=21\end{array}$ & $\begin{array}{c}\text { Зниження Т-індексу } \\
\text { за однією кісткою } \\
\mathrm{N}=27\end{array}$ & $\begin{array}{c}\text { Зниження Т-індексу } \\
\text { за двома кістками } \\
\mathrm{N}=31\end{array}$ & $\begin{array}{c}\text { Зниження Т-індексу } \\
\text { за трьома кістками } \\
\mathrm{N}=15\end{array}$ \\
\hline Нітротирозин, нмоль/мл & $14,4(12-18)$ & $19,6(14,8-53,1)^{*}$ & $18,2(10,1-42,6)^{\#}$ & $55,9(47,3-61,3)^{\#}$ \\
\hline
\end{tabular}

Примітка: * - p<0,05; \# - p<0,01; порівняно з пацієнтами із нормальною МЩКТ.

Відомо, що збільшення продукції оксиду азоту призводить до зниження МЩКТ за рахунок зменшення активності остеобластів та зростання активності остеокластів [12]. Підвищений ризик переломів у пацієнтів з ЦД може бути обумовлений накопиченням кінцевих продуктів глікозилювання у поперечних зшивках колагену, які ініціюють розвиток ОС та дисбаланс у кістковому ремоделюванні [13].

Для оцінки взаємовпливу ОС з МЩКТ та показниками, які характеризують перебіг ЦД, був проведений кореляційний аналіз. Рівень нітротирозину асоціювався з параметрами ультразвукової денситометрії, що підтверджено наявністю зворотного взаємозв'язку нітротирозину з Т-індексом променевої кістки $(r=-0,29, p<0,05)$, Т-індексом фаланги $(r=-0,25, p<0,05)$. Зростання концентрації НbA1c, тривалості ЦД та величини інсулінорезистентності достовірно асоціювалось з підвищенням рівня нітротирозину у сироватці крові (відпо- відно $r=+0,29, p<0,05, r=+0,27, p<0,05, r=+0,34$ $\mathrm{p}<0,05)$.

Таким чином, у пацієнтів з поєднаним перебігом ЦД та ОП наявна інтенсифікація оксидативного стресу, яка може бути проявом синдрому «взаємного обтяження». Логічно припустити, що, одночасно зі стандартною терапією, ці хворі повинні отримувати препарати із антиоксидантними властивостями

Висновки. 1. У хворих з поєднаним перебігом ЦД та ОП наявне збільшення виразності ОС, що підтверджено достовірним зростанням рівня нітротирозину у 2,8 раза, порівняно з хворими з ізольованим перебігом ОП, та у 2,1 раза - $з$ ЦД ( $<<0,05)$.

2. Рівень нітротирозину має вірогідний позитивний взаємозв'язок з НbA1c $(r=+0,29, p<0,05)$. Тривалість ЦД понад 10 років супроводжується підвищенням рівня нітротирозину у 2,3 раза, порівняно з пацієнтами, які хворіють на ЦД до 5 років $(p<0,05)$. 
Огляди літератури, оригінальні дослідження, погляд на проблему, ювілеї

3. Рівень нітротирозину асоціюється з параметрами ультразвукової денситометрії, що підтверджено зворотним взаємозв'язком нітротирозину та Т-індексу променевої кістки ( $r=-0,29$, $p<0,05)$, Т-індексу фаланги $(r=-0,25, p<0,05)$.

Перспективи подальших досліджень. Паці-

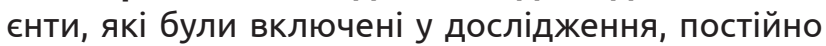

проживали в умовах промислового регіону, що може бути одним із факторів активації ОС. У подальших дослідженнях плануємо проаналізувати роль антропогенного навантаження на показники оксидативного стресу у хворих з поєднаним перебігом ЦД та ОП.

\section{ЛІТЕРАТУРА}

1. Руяткина Л. А. Состояние плотности костной ткани при сахарном диабете 2 типа / Л. А. Руяткина, А. В. Ломова, Д. С. Руяткин // Фарматека - 2013. - № 5 (258). С. 25-31.

2. Qian Wu. Advanced oxidation protein products as a novel marker of oxidative stress in postmenopausal osteoporosis / Qian Wu, Zhao-Ming Zhong, Ying Pan [et al.] // Medical Science Monitor. - 2015. - Vol. 21. - P. 2428-2432.

3. Pacher P. Nitric oxide and peroxynitrite in health and disease / P. Pacher, J. S. Beckman, L. Liaudet // Physiol. Rev. - 2007. - Vol. 87 (1). - P. 315-324.

4. Макурина Г. И. Нитрозирующий стресс при псориатической болезни в сочетании с эссенциальной гипертензией / Г. И. Макурина // Вестник проблем биологии и медицины - 2015. - № 3. - С. 159-165.

5. Official Positions of the International Society for Clinical Densitometry - 2015. [Electronic resource]. Mode access: https://iscd.app.box.com/v/OP-ISCD-2015-Adult

6. Мітченко О. І. Реалізація міжнародних рекомендацій щодо профілактики серцево-судинних захворювань у жінок: фокус на омега-3-поліненасичені жирні кислоти / О. І. Мітченко, В. Ю. Романов, Г. Я. Іллюшина // Український медичний часопис. - 2013. - № 2 (94). С. 107-109.

7. Ишонина О. Г. Особенности метаболических изменений в крови пациенток с сахарным диабетом 2 типа в зависимости от возраста и степени компенсации углеводного обмела / О. Г. Ишонина : автореферат дис. на соискание ученой степени кандидата биологических наук. $-2015 .-26$ с.

8. Азизова Г. И. Биомаркеры оксидативного стрес- са и состояние антиоксидантной системы при сахарном диабете типа 2 / Г. И. Азизова, А. Р. Дадашова, М. Ф. Амирова // Universum: Медицина и фармакология : электрон. научн. журн. - 2014. - № 6(7). [Електронний ресурс]. Режим доступу: URL: http://7universum. com/ru/med/archive/item/1386

9. https://www.ncbi.nlm.nih.gov/pubmed/?term= Grindel\%20A\%5bAuthor\%5d\&cauthor=true\&cauthor uid $=27598300 G$ rindel A. Oxidative Stress, DNA Damage and DNA Repair in Female Patients with Diabetes Mellitus Type 2/ A. Grindel, B. Guggenberger, L. Eichberger et. al. // PLoS One. - 2016. - Vol. 11(9)

10. «Порочный круг» взаимосвязи перекисного окисления липидов и окислительной модификации белков у больных сахарным диабетом 2-го типа / О. В. Занозина, Ю. А. Сорокина, Н. Н. Боровков [и др.] // Медицинский альманах. - 2013. - № 6. - С. 167-170.

11. Pyrrolidine dithiocarbamate protects pancreatic $\beta$-cells from oxidative damage through regulation of FoxO1 activity in type 2 diabetes rats/ H. Ding, T. Zhu, X. Yin [et al.] // Acta Biochim. Biophys. Sin. (Shanghai). 2014. - Vol. 46(7). - P. 582-589.

12. Сорокин Б. В. Характер ремоделирования костей при воспроизведении экспериментального остеопороза при хронической интоксикации нитрата натрия // Б. В. Сорокин, В. А. Костенко // Журнал Гродненского государственного медицинского университета. - 2013. № 4. - C. 074-077.

13. Kanazawa I. Interaction between bone and glucose metabolism / I. Kanazawa // Endocr. J. - 2017. Vol. 64 (11). - P. 1043-1053.

\section{REFERENCES}

1. Ruyatkina, L.A., Lomova, A.V., \& Ruyatkin, D.S. (2013). Sostoyaniye plotnosti kostnoy tkani pri sakharnom diabete 2 tipa [The state of bone tissue density in type 2 diabetes mellitus]. Farmateka - Farmateca, 5 (258), 25-31 [in Russian].

2. Qian, Wu, Zhao-Ming Zhong, \& Ying Pan, (2015). Advanced oxidation protein products as a novel marker of oxidative stress in postmenopausal osteoporosis. Medical Science Monitor, 21, 2428-2432. doi: 10.12659/MSM.894347

3. Pacher, P., Beckman, J.S., \& Liaudet, L. (2007). Nitric oxide and peroxynitrite in health and disease. Physiol. Rev., 87 (1), 315-324. doi: 10.1152/physrev.00029.2006

4. Makurina, G.I. (2015). Nitroziruyushchiy stress pri psoriaticheskoy bolezni v sochetanii s essentsialnoy gipertenziyey [Nitrosative stress in psoriatic diseases

combined with essential hypertension]. Vestnik problem biologii i meditsiny - Journal of Problems of Biology and Medicine, 3, 159-165 [in Russian].

5. Official Positions of The International Society for Clinical Densitometry (2015). Retrieved from: https://iscd. app.box.com/v/OP-ISCD-2015-Adult

6. Mitchenko, O.I., Romanov, V.Yu., \& Illiushyna, H.Ya. (2013). Realizatsiia mizhnarodnykh rekomendatsii shchodo profilaktyky sertsevo-sudynnykh zakhvoriuvan u zhinok: fokus na omeha-3-polinenasycheni zhyrni kysloty [Implementation of International Recommendations on the Prevention of Cardiovascular Diseases in Women: Focus on Omega-3-Polyunsaturated Fatty Acids]. Ukrainskyi medychnyi chasopys - Ukrainian Medical Journal, 2 (94), 107-109 [in Ukrainian]. 
Огляди літератури, оригінальні дослідження, погляд на проблему, ювілеї

7. Ishonina, O.G. (2015). Osobennosti metabolicheskikh izmeneniy v krovi patsiyentok s sakharnym diabetom 2 tipa v zavisimosti ot vozrasta i stepeni kompensatsii uglevodnogo obmena [Features of metabolic changes in the blood of patients with type 2 diabetes mellitus depending on the age and degree of compensation of carbohydrate metabolism]. Candidate's Extended abstract [in Russian].

8. Azizova, G.I., Dadashova, A.R., \& Amirova, M.F. (2014). Biomarkery oksidativnogo stressa i sostoyaniye antioksidantnoy sistemy pri sakharnom diabete tipa 2 [Biomarkers of oxidative stress and the state of the antioxidant system in type 2 diabetes mellitus]. Universum: Meditsina i farmakologiya: elektron. nauchn. Zhurn. - Universum: Medicine and Pharmacology: Electronic Scientific Journal, 6 (7). Retrieved from: http://7universum.com/ru/ med/archive/item/1386. [in Russian].

9. Grindel, A., Guggenberger, B., \& Eichberger, L. (2016). Oxidative Stress, DNA Damage and DNA Repair in Female Patients with Diabetes Mellitus Type 2. PLoS One, 11 (9). doi: 10.1371/journal.pone.0162082.

10. Zanozina, O.V., Sorokina, Yu.A., \& Borovkov, N.N. (2013). "Porochnyy krug" vzaimosvyazi perekisnogo okisle- niya lipidov i okislitelnoy modifikatsii belkov u bolnykh sakharnym diabetom 2-go tipa ["Vicious circle" of the relationship between lipid peroxidation and oxidative modification of proteins in patients with type 2 diabetes mellitus]. Meditsinskiy almanakh - Medical Almanac, 6, 167-170 [in Russian].

11. Ding, H., Zhu, T., \& Yin, X. (2014). Pyrrolidine dithiocarbamate protects pancreatic $\beta$-cells from oxidative damage through regulation of FoxO1 activity in type 2 diabetes rats. Biochim. Biophys. Sin. (Shanghai), 46 (7), 582589. doi: 10.1093/abbs/gmu034

12. Sorokin, B.V., \& Kostenko, V.A. (2013). Kharakter remodelirovaniya kostey pri vosproizvedeniye eksperimentalnogo osteoporoza pri khronicheskoy intoksikatsii nitrata natriya [Character of remodeling of bones during reproduction of experimental osteoporosis in chronic intoxication of sodium nitrate]. Zhurnal Grodnenskogo gosudarstvennogo meditsinskogo universiteta - Journal of Grodno State Medical University, 4, 074-077 [in Russian].

13. Kanazawa, I. (2017). Interaction between bone and glucose metabolism. Endocr. J., 29, 64 (11), 1043-1053. doi: 10.1507/endocrj.EJ17-0323.

\title{
СОСТОЯНИЕ ОКСИДАТИВНОГО СТРЕССА У ПАЦИЕНТОВ С СОЧЕТАННЫМ ТЕЧЕНИЕМ САХАРНОГО ДИАБЕТА 2 ТИПА И ОСТЕОПОРОЗА
}

\author{
๑В. И. Кривенко, О. И. Бородавко \\ Запорожский государственный медицинский университет
}

РЕЗЮМЕ. Одним из факторов, который может влиять на развитие и прогрессирование как сахарного диабета 2 типа (СД), так и остеопороза (ОП), является оксидативный стресс (ОС). Однако в литературе мы не нашли сообщений о выраженности ОС у больных с сочетанным течением СД и ОП.

Цель работы - оценить состояние оксидативного стресса у больных с сочетанным течением сахарного диабета 2 типа и остеопороза.

Материал и методы. В исследование включено 94 человека (от 50 до 70 лет). В 1 группу вошли 22 больных ОП, во 2-22 пациента с СД, в 3-50 больных с сочетанным течением СД и ОП. Всем пациентам проводили ультразвуковую денситометрию на ультразвуковом денситометре Omnisense 7000 (BeamMedLtd, Израиль). Оценку состояния костной ткани проводили по критериям ВОЗ. Интенсивность ОС оценивали по уровню нитротирозина в сыворотке крови. Пациентам с СД определяли глюкозу натощак, НbA1c, инсулин и расчет индекса НОМА.

Результаты. У больных с сочетанным течением СД и ОП имеет место увеличение выраженности ОС, что подтверждено достоверным повышением уровня нитротирозина в 2,8 раз по сравнению с больными с изолированным течением ОП и в 2,1 раза - с СД $(p<0,05)$. Уровень нитротирозина имеет достоверную положительную взаимосвязь с HbA1c ( $r=+0,29$, p <0,05). Продолжительность СД более 10 лет сопровождается повышением уровня нитротирозина в 2,3 раза, по сравнению с пациентами, страдающим СД до 5 лет ( $<<0,05)$. Уровень нитротирозина ассоциировался с параметрами ультразвуковой денситометрии, что подтверждено обратной взаимосвязью нитротирозина с Т-индексом лучевой кости ( $r=-0,29, p<0,05)$, Т-индексом фаланги $(r=-0,25, p<0,05)$.

Выводы. У пациентов с сочетанным течением СД и ОП имеет место интенсификация оксидативного стресса, который может быть проявлением синдрома «взаимного отягощения». Логично предположить, что наряду со стандартной терапией, эти больные должны получать и препараты с антиоксидантными свойствами.

КЛЮЧЕВЫЕ СЛОВА: оксидативный стресс; сахарный диабет 2 типа; остеопороз. 


\section{STATE OF OXIDATIVE STRESS IN PATIENTS WITH COMBINED COURSE OF TYPE 2 DIABETES MELLITUS AND OSTEOPOROSIS}

@V. I. Kryvenko, O. I. Borodavko

\section{Zaporizhzhia State Medical University}

SUMMARY. Oxidative stress (OS) is one of the factors that can affect the development and progression of type 2 diabetes mellitus (DM) and osteoporosis (OP). In the literature, we did not find information about the state of the OS in patients with combined course of DM and OP.

The aim of the study - to investigate the state of oxidative stress in patients with a combined course of type 2 diabetes mellitus and osteoporosis.

Material and Methods. Study of 94 patients, among whom group $1-22$ patients with osteoporosis (OP), group 2 - 22 patients with type 2 diabetes mellitus (DM), group 3 - 50 patients with combined course of these diseases. An ultrasound densitometry on an Omnisense 7000 ultrasound densitometer (BeamMedLtd, Israel) was performed for all patients. The bone tissue state was determined according to WHO criteria. The intensity of the OS was investigated by the level of nitrotyrosine in serum. Patients with type 2 DM were studied for glucose, HbA1c, insulin, and HOMA index.

Results. In patients with combined course of DM and OP, the severity of the OS increases, which is confirmed by a significant increase in the level of nitrotyrosine in 2.8 times compared with patients with isolated flow of OP and 2.1 times - with diabetes $(p<0.05)$. The nitrotyrosine level had significant positive correlation with HbA1c $(r=+0.29, p<0.05)$. Duration of DM more than 10 years is accompanied by an increase in the level of nitrotyrosine in 2.3 times compared with patients who have diabetes until 5 years old $(p<0.05)$. The nitrotyrosine level had significant correlation with parameters ultrasound densitometry, which is confirmed by the negative correlation nitrotirosine and T-index of radial bone ( $r=-0.29$, $p<0.05)$, T-index of phalanx $(r=-0.25, p<0.05)$.

Conclusions. In patients with combined course of DM and OP, there is an intensification of oxidative stress, which can be a manifestation of a "reciprocal encumbrance" syndrome. We can assume that along with standard therapy, these patients should receive antioxidant drugs.

KEY WORDS: oxidative stress; type 2 diabetes mellitus; osteoporosis. 